\title{
My Dear White Sister: Self-examining White Privilege and the Myth of America
}

Keely Shinners University of Cape Town

\begin{abstract}
James Baldwin, in his landmark essay "My Dungeon Shook," says that white Americans are "still trapped in a history which they do not understand; and until they understand it, they cannot be released from it." This open letter explores this history on a personal level. Taking notes from Baldwin's indictments of whiteness in Another Country and The Fire Next Time, this essay explores how white people, despite claims of deniability, become culpable, complicit, and ensnared in their racial privilege. By reading Baldwin's work through a personal lens, it implores fellow white readers and scholars of Baldwin to begin examining the myths of America by first examining themselves.
\end{abstract}

Keywords: James Baldwin, Another Country, The Fire Next Time, white imagination, racial privilege

I have begun this letter five times and torn it up five times. I keep seeing your face, which is also the face of our mother, our grandmother, our great-grandmother. I keep seeing your eyes which, like the sky, cannot be seen through, which, like the sky, say nothing at all.

At the bottom of your heart, you really believe what white people say about you. And why wouldn't you?

They are, in effect, still trapped in a history which they do not understand; and until they understand it, they cannot be released from it. ${ }^{1}$

My dear white sister, do you remember having always been white? Of course, you had been told you were white before you could even say your own name. Liv-named after Liv Tyler, daughter of the lead singer of Aerosmith, "America's 
Greatest Rock and Roll Band."2 Olivia, one of 10,610 Olivias born in the United States between 1996 and 2005. ${ }^{3}$ Your assimilation to the homogeneous narrative of our nation, our fellow countrymen, was expected of you, etched onto your birth certificate moments after you took your first breath.

And no one could stop talking about your eyes. So big! they said. So beautiful! So blue! In the dark of the bedroom we shared, I remember hearing our mother, from the edge of your bed, singing softly, "Linger on, your pale blue eyes." ${ }^{\text {L }}$ Linger on. Linger on. Do you think our mother was anxious that you might give up on your blue eyes?

In our mother's mind, those pale blue eyes, I think, meant something. Twentysix of our presidents, after all, had blue eyes. ${ }^{5}$ As did Elizabeth Taylor and Marilyn Monroe; there were photographs of them hanging in our father's garage. Blue, the color of the house we lived in, in a nearly-all-white neighborhood in our tiny town in northern Illinois. Blue, the trademarked color of the universities for which our parents, who couldn't go to university, saved their entire lives. Blue, the color of those "Gulf stream waters," that "endless skyway," in the land that was made "for you and me."

The details and symbols of your life have been deliberately constructed to make you believe what white people say about you. Please try to remember that what they believe, as well as what they do and cause you to endure, does not testify to your inferiority but to their inhumanity and fear. ${ }^{7}$

Blue, which is also a trap. Because once you start looking for blue, you see it everywhere. In the dishes our mother used when friends came over, the dishes we weren't allowed to touch. In the tarps our dad put on the house to protect the sagging roof from the weight of snow. Blue, the "big blue" ocean, a blue that conceals its depths. All the thrashing, the short breath, the longing for life down there. Blue, worse than darkness, because it offers the promise of a clarifying light. Blue, a dissolution of the truth. Unbearable, tumultuous, and blood-pounding blue.

Our mother hummed you lullabies so that your blue eyes, like her blue eyes, and her mother's and her mother's, might carry on.

Did you pray, as Pecola prays in Toni Morrison's debut novel, for those pretty blue eyes? "Blue-sky eyes... Morning-glory-blue-eyes. Alice-and-Jerryblue-storybook-eyes."

Did blue mean anything to you before you knew you were seeing out of it?

Because you and I both know that pale blue eyes are merely symptomatic of a genetic mutation affecting the OCA3 chromosomal gene code, a mutation originating from a single ancestor who lived seven thousand years ago. Found in the skeleton of a mesolithic hunter-gatherer, buried in a deep cave system near León in northwestern Spain. Apparently, the anthropologists could read his eye color from DNA embedded in a tooth.

Carles Lalueza-Fox of the Institute of Evolutionary Biology in Barcelona said of the "discovery," "The biggest surprise was to discover that this individual possessed 
African versions of the genes that determine the light pigmentation of the current Europeans, which indicated that he had dark skin."

Blue, a false trap, because no real eye is blue. "Neither blue nor green pigments are ever present in the human iris or ocular fluid." ${ }^{10}$ Cut your eye open, my dear white sister, and you'll find your pretty, big, beautiful blue eyes have always been swimming in blackness. Blue eyes refract light, like the sky, nothing but a scattering. And yet we see our whole lives up there. Blue, a reflection.

When you look into the tyranny of your mirror, do you get lost in the impossible maze of that blue? Are you trapped in a history of blue?

Until you understand this, you cannot be released from it.

My dear white sister, when you dream your reality away, do you dream in blue?

In this case, the danger, in the minds of most white Americans, is the loss of their identity. Try to imagine how you would feel if you woke up one morning to find the sun shining and all the stars aflame. ${ }^{11}$

Our Aunt Francine used to write short stories for you, all of them starring the Little Blue Eyed Girl. Titles like, “The Little Blue Eyed Girl Goes to the Beach." Or, “The Little Blue Eyed Girl's First Day of School." Your favorite story, I remember, was "The Little Blue Eyed Girl Goes on a Picnic." In the story, the Little Blue Eyed Girl goes for an afternoon luncheon in the park with her little white dog. They eat peanut butter jelly sandwiches and baby carrots out of small plastic bags. They drink lemonade. The climax of the story occurs when the Little Blue Eyed Girl suddenly discovers that her little white dog has run off into the woods without her. She is sure that she has lost the dog forever. And who would she be without the little white dog? Panic. A deep and childish cry.

It was your favorite story. I never knew why. What could have been so terrifying about those shadows behind the trees?

I hear Ida from Another Country saying to Cass,

You think we're in a goddamn park. You don't know we're in one of the world's great jungles. You don't know that behind all them damn dainty trees and shit, people are screwing and sucking and fixing and dying. Dying, baby, right now while we move through this darkness in this man's taxicab. And you don't know it, even when you're told; you don't know it, even when you see it. ${ }^{12}$

Yes, there seems to be a whole world out there, waiting to swallow up the Little Blue Eyed Girl. She fears losing herself in it. But she does not accept it. She will not accept it.

Cass, too, does not accept it: "And she, too, looked out at the park, trying to see what Ida saw; but, of course, she saw only the trees and the lights and the grass and the twisting road and the shape of the buildings beyond the park." ${ }^{13}$ A refusal to accept reality beyond what can be seen from the framework of the blue-eyed dream. 
In the end, of course, nothing happens to the Little Blue Eyed Girl. The small white dog returns. They finish their sandwiches and lemonade and the Little Blue Eyed Girl returns to a warm home with her dog in the bicycle basket. Nothing bad happens to the Little Blue Eyed Girl because nothing bad is supposed to happen to her.

There's dying, baby, right there beyond the pines. It was your favorite story. Do you think you ever noticed it?

Dying, and the Blue Eyed Girl shuts her eyes to cry, seeing nothing.

Something very sinister happens to the people of a country when they begin to distrust their own reactions as deeply as they do here, and become as joyless as they have become. It is this individual uncertainty on the part of white American men and women, this inability to renew themselves at the fountain of their own lives, that makes the discussion, let alone elucidation, of any conundrum-that is, any reality-so supremely difficult. The person who distrusts himself has no touchstone for reality-this touchstone can only be oneself. ${ }^{14}$

When you were young, your favorite movie was Cinderella. You watched the movie every day, never tiring of its parables and clichés. You watched the movie every day, and, what I think is even more crucial, you pretended to be Cinderella every day afterwards. Dressed up in a sparkling dress our mother made for you one Halloween. You would replay the screenplay to yourself. The fairy godmother's glorious metamorphosis. The luxury of the ball. The midnight crisis. The wedding ceremony, cathartic, when justice is delivered to the poor girl with ashes on her face.

And my dear white sister, I remember you singing the same damn song, over and over again, "Because these daft and dewey eyed dopes/keep building up impossible hopes/impossible things are happening every day!" Sung by Whitney Houston, who plays the fairy godmother in the 1997 TV film, starring Brandy as Cinderella. It was the only VHS copy of that ages-old narrative we had. I've never known why, out of all the VHS tapes of that ages-old narrative, our parents purchased the version which the New York Times called "blissfully multiethnic."15 As young children, barely able to tie our own shoes, there was no cause to doubt that one step-sister could be black and the other white, nor a black queen in Whoopi Goldberg, a white king in Victor Garbers and the Philippine-born Paolo Montalbán as their Prince Charming. Of course, as the New York Times says, "The fact that this racial utopia exists in a fairy tale only emphasizes its distance from reality." ${ }^{16}$ But you were always playing Brandy, as Cinderella, singing back to Whitney, "Impossible ... It's possible," dancing around our basement in your glittering dress.

You have grown out of Cinderella, as many of us do. But I worry that you have also lost this sense of possibility and have grown to favor that which is impossible. I worry that this might render you joyless, with time. It is difficult to renew one's life when one firmly believes there is only one type of living available to them. 
What is even more worrisome, however, is not that you have grown out of Cinderella but that you have stopped recognizing her in your own face. That your imagination has been released from what Homi Bhabha would call "being together," the "double-edged movement" of "seeing oneself as another."17

When, if it did happen, did Brandy become other to you, a spinoff of history instead of the central narrative? A narrative apart from yours?

When did you stop playing Cinderella?

It is not permissible that the authors of devastation should also be innocent. It is the innocence which constitutes the crime. ${ }^{18}$

I know this was a force you didn't ask for. No one gets to decide what house one is brought home to, kicking and screaming. No one gets to decide the first words one speaks. Yours was, "Papa." Indeed, we are still too dumb to speak out in opposition when our mothers dress us in gossamer to be baptized in the big white church down the road.

No one chooses to be born in the middle of nowhere, in such an abandoned town as ours. Fox Lake, Illinois, city of sinkholes. A town that has always felt empty of something. Ghosts in the booths of every restaurant. Cemeteries without ghosts. Too far away from Chicago to be considered a suburb. Too wet and heavy from the Chain O' Lakes for the cornfields to grow. Fox Lake, Illinois, population 8,822 when you were born, $95.49 \%$ white. ${ }^{19}$ It was difficult to know what to do in a place like that. Other than to hide, for a while, and then to leave.

I hear you, and I hear myself too, desperate, young, and naive, when Cass says:

"There were hardly any colored people in the town I grew up in-how am I to know?"

And she hated herself for her next question, but she couldn't hold it back: "Don't you think I deserve some credit, for trying to be human, for not being a part of all that, for-walking out?"20

I moved out of concealment to California. I read Another Country on the plane. I cried when Rufus missed his stop on the subway, and I cried when Yves kissed Eric on the train platform, saying, Ne moublie pas. I cried all the way to California, and then I called you, said of our hometown, "You have to get the fuck out of there."

Was this walking out?

My dear white sister, you are now moving to Los Angeles in the fall. Our family produced two daughters, now, with the capacity for breaking a geographical legacy.

Ida says, "What the hell have you walked out on?" 1

I remember a time when our father hung a Confederate flag in the window of his garage. I remember our shame over him. We told ourselves our father was ignorant, and we were ashamed for all "the things he did not understand." We were ashamed, which was the same shame we felt when we watched the news in the morning, streaming from the segregated Chicago streets. The same shame when we wore white to Sunday school. When we heard kids fighting at the back of the 
school bus and tried to keep our eyes on the road ahead. The shame that "defines within its terms the mental horizon." 22 The shame that carries with it the "stamp of legitimacy . . coterminous with what is 'natural,' 'inevitable."'23

We were ashamed, but we did not confront our father about the flag. We were ashamed because we did not confront our father about the flag. We took it down. We hid it. But we did not throw it away. We took it down and hid it but in doing so we accepted it as a part of the house, and, by extension, perhaps, a part of ourselves, part of our inhabited mental framework.

A force you didn't ask for.

We were ashamed, but we did not walk out. Because to walk out does not mean to hide. To walk out does mean to leave. There is only a world to walk out on, and we were ashamed of that world. "This world" which "is white," where there is another unknown, "they" who are "black." 24 And we were afraid to walk out of a world in which there was an identifiable "this" or "they."

We hid in our innocence, which constitutes the crime.

I hear the chorus of the innocents screaming, "No! This is not true! How bitter you are!"- but I am writing this letter to you, to try to tell you something about how to handle them, for most of them do not yet really know that you exist. I know the conditions under which you were born, for I was there. Your countrymen were not there, and haven't made it yet. Your grandmother was also there, and no one has ever accused her of being bitter. I suggest that the innocents check with her. She isn't hard to find. Your countrymen don't know that she exists, either, though she has been working for them all their lives. ${ }^{25}$

A force which you didn't ask for.

But not, my dear white sister, a destiny which you must accept.

She isn't hard to find. Still, you do not recognize her. You cannot find her.

Your shame, my dear sister, is the same shame Cass feels driving down Seventh Avenue, "startling ... the entire population seemed to be in the streets, draped, almost, from lampposts, stoops, and hydrants." 26 The shame shakes her bones, your bones, so that she has to look away, and you too look away. Cross your legs. Light a cigarette.

And so, Ida says, in the face of your embarrassment,

They keep you here because you're black, the filthy white cock suckers, while they go around jerking themselves off with all that jazz about the land of the free and the home of the brave. And they want you to jerk yourself off with the same music, too, only, keep your distance. ${ }^{27}$

You are embarrassed now because she has shown you that you can no longer be innocent.

Now that you can no longer be innocent, you feel power welling up inside of you. You remember everything about your blue eyes and their "cash value." ${ }^{28}$ 
Seeing through blue eyes means seeing "profits made from housing secured in discriminatory markets, through unequal educations . . . through insider networks ... through intergenerational transfers of inherited wealth." ${ }^{29}$

You feel power trembling against your shoes, your tights, your fingernails. You feel it surrounding the taxicab, building a wall of fog between you and the passersby, between you and Ida, sitting next to you, between you and the taxi driver. And, against this abyss, anger from the people railing against the injustice of you. You feel sorry, and you may even whisper the word "privilege" to yourself, you who thinks she has as opposed to those who do not have.

But again, my dear white sister, you have failed. Power is real, and you have acknowledged that power is real. But you have once again believed the kinds of stories people tell you.

Power has not erased the woman you are looking for. It appears that she does not "exist" because you cannot recognize yourself in her. Which is the same reason why Ida does not exist, and neither do the people draped on the streets of Harlem, nor the taxi driver. You have misrecognized them by assuming your power has everything to gain, while they have everything to lose. They do not "exist" because you think that you cannot know them.

My dear white sister, you have known them your entire life. You knew them when you glittered about our basement, shouting to the limits of knowledge, "Impossible things are happening every day!”

When did you stop playing Cinderella?

Such a person interposes between himself and reality nothing less than a labyrinth of attitudes. And these attitudes, furthermore, though the person is usually unaware of it (is unaware of so much!), are historical and public attitudes. They do not relate to the present any more than they relate to the person. Therefore, whatever white people do not know about negroes reveals, precisely and inexorably, what they do not know about themselves. ${ }^{30}$

You think you cannot know them because you do not know yourself. You have missed something.

Ida explains precisely what it is: "What you people don't know ...is that life's a bitch, baby. It's the biggest hype going. You don't have any experience in paying your dues and it's going to be rough on you, baby, when the deal goes down." ${ }^{31}$

What you do not know about yourself, my dear sister, is how much you stand to lose. The panic felt by the Little Blue Eyed Girl when she loses her little white dog is the same panic felt by the white American driving down Seventh Avenue, confronted with reality. Not an other reality, but a very personal one. Who are you if not your shoes and your tights and your fingernails? Who are you if not the trees and the twisting road beyond them? Who are you if not your bicycle and picnic basket? Who are you if not cash value, a big blue house in a white neighborhood, a history textbook, or a check in the mail?

Who are you if not your blue eyes? 
You think you are glittering with your privilege, my love, but you and I both know you are only one strike of the clock away from the cinders.

What we do not wish to face, and what white Americans do not face when they regard a negro: reality - the fact that life is tragic. Life is tragic simply because the earth turns and the sun inexorably rises and sets, and one day, for each of us, the sun will go down for the last, last time... We sacrifice all the beauty of our lives ... imprison ourselves in totems, taboos ... races, armies, etc.... to deny the fact of death, which is the only fact we have... White Americans do not believe in death, and this is why the darkness of my skin so intimidates them. ${ }^{32}$

So, my dear white sister, you are intimidated. You are intimidated because you can suffer, and "you've got some suffering to do, believe me." 33

You can suffer. I know because I have watched you suffer, as you have watched me suffer. This is what has bound us together across space and time. This is why I am writing to you now, to tell you that it is your responsibility to suffer. It is the acceptance of your struggle-which is universal, and daily-that will set you free from the tyranny of your mirror.

A motorcycle accident when we were young. Our father hit a guardrail, then a car, then another guardrail. One of his eyes was forced out of its socket. The paramedics put his eye in a plastic cup and taped it to his cheek so as not to rupture the optic nerve.

Our father's eye-blue, like yours.

The possibility of blindness. The possibility of brain damage. The possibility of death.

I bring this up now because in the possibility of losing everything-our future, our location, our mother as we knew her, our home as we knew it-a veil was lifted. With the risk of losing it all, I think we truly fell into love. Love, being, of course, "not merely in the personal sense but as a state of being, or a state of grace." ${ }^{34}$ Love, like a paradox. Love full to a terrifying brim. Love like a "third space." 35 Love as a lull and a fright and an anguish. Love as a shared suffering, in times of voice and quiet, in times of heat and cold.

I remember the world transforming before us. Our mother looked, suddenly, very frightened, and very young, because we were all very frightened and very young. Our grandmother would say things like, "This is the first thing I've eaten today," long into the evening, which was crucial, because we, too, had forgotten to eat. And I remember the nurse whose brother was losing his memory. And I remember the doctor who was losing his hair. And I remember the woman from the soap opera that played in the waiting room, crying over her husband's affairs. Because all this suffering was happening to us, too.

Love takes off the masks that we fear we cannot live without and know we cannot live within. I use the word 'love' here not merely in the personal sense but as a state of being, or a state of grace. ${ }^{36}$ 
To love, to cast off the masks of innocence, power, and shame. To love, to walk out of that individual mind which cannot sustainably be lived within. Love, through suffering, through a recognition of suffering, to freedom.

My dear sister, it is time to free yourself into love. Love will tear you from your mask. For when you love, there is no longer a strange, foggy abyss between you and Brandy's Cinderella, between you and Whitney's fairy godmother, the trees in the park and everyone and everything between their shadow and their light. No separation between you and Ida, you and the taxi driver, Baldwin's mother and all the people from Seventh Avenue to Fifth.

It will not be an easy love, my dear sister. "You stand to lose everything," because you will have to put your body on the line. ${ }^{37}$ You will have to give up on that terrible labyrinth of attitudes. It will mean that people may try to kill you in the morning, as people killed Bill Moore, as they killed Jimmy Lee Jackson and Herbert Lee. ${ }^{38}$

The signs following the protests of Bill Moore's death proclaimed: "Moore Died for Love. Let's Live and Act in Love." ${ }^{39}$

Put your body on the line. Live and act in love because you cannot live within the alternative. Walk out of fear and shame and into love.

Put your body on the line, which means standing on the street corner in the cold, not faltering when the flash bangs sound. Put your body on the line, which means staying up until four in the morning with your best friend, who is heartbroken, when she wants to talk to you about it and when she doesn't. Put your body on the line, which means keeping Ida's secret and staying with her when she asks you to. Which means reaching out to kiss Rufus on the train platform the same way Yves kisses Eric. Ne moublie pas. Don't forget about me. Know who I am. I am you, too.

And what is even more essential, my dear white sister, is that you must learn to love and accept yourself, your fear of suffering, your fear of death.

White people in this country will have quite enough to do in learning how to accept and love themselves and each other, and when they have achieved this-which will not be tomorrow and may very well be never-the negro problem will no longer exist, because it will no longer be needed. ${ }^{40}$

This, of course, will be the hardest thing to do, because there will be a million or more strange voices telling you that you don't have to do it.

It will be difficult to begin, learning how to love oneself. To grapple with one's history. To sit with the reality of fear and death. To love without one's mask. And I do not think I can do it for you, but here is a potential departure point:

From as far as I can see, you eyes have never been blue. Not once have I looked into a sky that can't be seen through and thought of you. If your eyes are any color, they might be gray. Gray, like the murky waters of the Seine. And wide, like the bell-bottom jeans brushing along the pavement beside the Seine. Bright, like dawn when the curtains are drawn. And longing, longing above all, like a cigarette first thing in the morning, before breakfast, watching the light pour in. 


\section{Notes}

1 James Baldwin, "My Dungeon Shook," in The Fire Next Time (New York, Dial Press, 1963), p. 22.

2 Melinda Newman, “The Billboard Interview-Aerosmith," Billboard, 110:33 (1998), pp. 19-20.

3 “100 Most Popular Baby Names of 1998," WeddingVendors.com, www.weddingvendors. com/baby-names/popular/1998/ (accessed 13 March 2018).

4 The Velvet Underground, "Pale Blue Eyes," The Velvet Underground (45th Anniversary/Deluxe Edition) (Santa Monica, CA, Universal Records, 2014).

5 Bob Greene, "History Shows That the Eyes Have It," Chicago Tribune, 3 October 1998, http://articles.chicagotribune.com/1988-10-03/features/8802040884_1_blueeyes-presidents-men (accessed 13 March 2018).

6 Woody Guthrie, "This Land Is Your Land," The Asch Recordings, Vol. 1 (Washington D.C., Smithsonian Folkways Recordings, 1997).

7 Baldwin, "My Dungeon Shook," p. 22.

8 Toni Morrison, The Bluest Eye (New York, Vintage Books, 2007), p. 46.

9 Steve Connor, "Revealed: First Ol' Blue Eyes is 7,000 Years Old and Was a Caveman Living in Spain," The Independent, 26 January 2014, www.independent.co.uk/news/ science/revealed-first-ol-blue-eyes-is-7000-years-old-and-lived-in-a-cave-9086310.html (accessed 13 March 2018).

10 Denis Llewellyn Fox, Biochromy: Natural Coloration of Living Things (Berkeley, CA, University of California Press, 1979), p. 56.

11 Baldwin, “My Dungeon Shook," p. 22.

12 James Baldwin, Another Country (New York, Vintage Books, 1993), p. 348.

13 Ibid.

14 James Baldwin, "Down at the Cross: Letter from a Region in My Mind," in The Fire Next Time (New York, Dial Press, 1963), p. 57.

15 Caryn James, “The Glass Slipper Fits With a 90s Conscience," The New York Times, 31 October 1997, p. 29.

16 Ibid.

17 Homi K. Bhabha, "Our Neighbors, Ourselves: Contemporary Reflections on Survival," in Hegel Lectures (Berlin, De Gruyter, 2010), p. 18.

18 Baldwin, “My Dungeon Shook," p. 25.

19 "Census of Population and Housing," 1 July 2016, www.census.gov (accessed 13 March 2018).

20 Baldwin, Another Country, p. 348.

21 Ibid.

22 Stuart Hall, "Encoding/Decoding," in Simon During (ed.), The Cultural Studies Reader (London, Routledge, 1993), p. 172.

23 Ibid.

24 Baldwin, “My Dungeon Shook," p. 39.

25 Ibid., p. 20.

26 Baldwin, Another Country, p. 350.

27 Ibid.

28 George Lipsitz, "Bill Moore's Body," in The Possessive Investment in Whiteness (Philadelphia, PA, Temple University Press, 1998), p. vii. 
29 Ibid.

30 Baldwin, "Down at the Cross," p. 58.

31 Baldwin, Another Country, p. 350.

32 Baldwin, "Down at the Cross," p. 105.

33 Baldwin, Another Country, p. 350.

34 Baldwin, "Down at the Cross," p. 105.

35 Bhabha, "Our Neighbors, Ourselves," p. 18.

36 Baldwin, "Down at the Cross," p. 105.

37 Baldwin, Another Country, p. 351.

38 Lipsitz, "Bill Moore's Body," p. xiv.

39 Ibid, p. x.

40 Baldwin, "My Dungeon Shook," p. 20.

\section{Works Cited}

“100 Most Popular Baby Names of 1998," WeddingVendors.com, www.weddingvendors. com/baby-names/popular/1998/ (accessed 13 March 2018).

Baldwin, James, Another Country (New York, Vintage Books, 1993).

"Down at the Cross: Letter from a Region in My Mind," in The Fire Next Time

(New York, Dial Press, 1963), pp. 41-128.

"My Dungeon Shook," in The Fire Next Time (New York, Dial Press, 1963), pp. 1-40.

Bhabha, Homi K., "Our Neighbors, Ourselves: Contemporary Reflections on Survival," in Hegel Lectures (Berlin, De Gruyter, 2010), pp. 1-19.

"Census of Population and Housing," 1 July 2016, www.census.gov/quickfacts/fact/ map/foxlakevillageillinois/PST045216 (accessed 13 March 2018).

Connor, Steve, "Revealed: First Ol' Blue Eyes is 7,000 Years Old and Was a Caveman Living in Spain," The Independent, 26 January 2014, www.independent.co.uk/news/ science/revealed-first-ol-blue-eyes-is-7000-years-old-and-lived-in-a-cave-9086310.html (accessed 13 March 2018).

Fox, Denis Llewellyn, Biochromy: Natural Coloration of Living Things (Berkeley, CA, University of California Press, 1979).

Greene, Bob, "History Shows That the Eyes Have It," Chicago Tribune, 3 October 1998, http://articles.chicagotribune.com/1988-10-03/features/8802040884_1_blue-eyespresidents-men (accessed 13 March 2018).

Guthrie, Woody, "This Land Is Your Land," The Asch Recordings, Vol. 1 (Washington D.C., Smithsonian Folkways Recordings, 1997).

Hall, Stuart, "Encoding/Decoding," in Simon During (ed.), The Cultural Studies Reader (London, Routledge, 1993), pp. 90-103.

James, Caryn, "The Glass Slipper Fits With a 90s Conscience," The New York Times, 31 October 1997, p. 29.

Lipsitz, George, "Bill Moore's Body," in The Possessive Investment in Whiteness (Philadelphia, PA, Temple University Press, 1998), pp. vii-xx.

Morrison, Toni, The Bluest Eye (New York, Vintage Books, 2007).

Newman, Melinda, “The Billboard Interview-Aerosmith,” Billboard, 110:33 (1998), pp. 19-20.

The Velvet Underground, "Pale Blue Eyes," The Velvet Underground (45th Anniversary/ Deluxe Edition) (Santa Monica, CA, Universal Records, 2014). 


\section{Contributor's Biography}

Keely Shinners is a writer and critic from Fox Lake, Illinois. They recently graduated with a B.A. in English from Scripps College in Claremont, California and are currently working on their Master's in Creative Writing at the University of Cape Town, South Africa. 